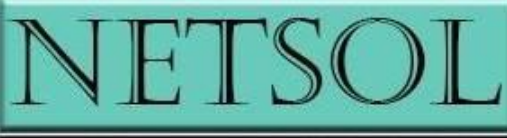

NEW TRENDS IN SOCIAL AND LIBERAL SCIENCES

An Interdisciplinary Journal

http://www.netsoljournal.net/

Volume 4, Issue 2, pp.44-61, Fall 2019

https://doi.org/10.24819/netsol2019.07

Date Submitted: February 4, $2019 \quad$ Date Accepted: November 11, 2019

\title{
Eat to Live or Live to Eat: Metaphor and Truth
}

\section{Prakash Kona}

\section{The English and Foreign Languages University, Hyderabad, India}

\begin{abstract}
Does the act of eating literally precede the birth of language as metaphor for knowing the truth? Can we think of a language that talks about food without thinking of food as the basis of human languages? Is there a truth to eating outside the discourse of language as the idealized representation of the human condition? Are we ever thinking of anything apart from food? Or, are we thinking at all when we are not thinking of eating? If the structure of our thinking is about food, to think of something other than food is to turn language into a shibboleth without a material basis to it. To think of eating in opposition to thinking where you do not have to talk about eating is to privilege the mind over the body. Food is the substructure to the superstructure of thought; to eat is to take arms against a sea of ideals; more importantly, it is to root our understanding of metaphor within a politics of eating; it is to look for truth in whether someone has eaten or not eaten playing a determining role in the formation of ideas about the world. Writing and popular culture have one thing in common which is that they must balance the demands that eating will make in the assertion of one's humanity with the ideas about humanity that perhaps have little to do with the activity of eating. This paper argues that in the acknowledgment of eating as central to any notion of the truth, we make food interchangeable with how we ingest a metaphor so much so that we are left wondering why there are people who go to sleep on empty stomachs!
\end{abstract}

Key Words: Food, Metaphor, Literal, Truth, Ethics

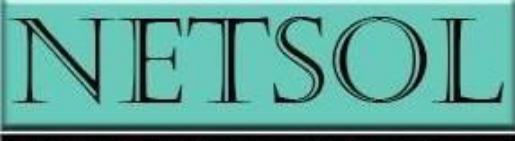

NEW TRENDS IN SOCIAL AND LIBERAL SCIENCES 
The economist Arthur MacEwan in his book Neo-liberalism or Democracy? Economic Strategy, Markets and Alternatives for the 21st Century, while speaking of larger questions related to social and economic justice, in a characteristically anecdotal manner, refers to a couple of events in relation to food. He begins a chapter titled, "Economic growth and the distribution of Income," with an experience of having lived in Karachi, Pakistan during the 1960s when his "neighbors had their cook feed the dog a pound or more of raw hamburger, probably more meat than the cook's family - or for that matter, most Pakistani families - ate in a month" (1999: 66). He adds further down, "I suppose there was something about the cook, who himself was poor, doing the actual feeding of the dog that aroused my moral indignation" (199: 66). He goes on to say that he was never comfortable with the idea of pets getting fed more than people despite the fact that he loved dogs. Another instance, MacEwan talks about in the same book, while introducing an argument in the chapter, "The Bases of a Democratic Alternative: Definitions and Context" is a reference to a radio comedy he heard as a teenager which involved an argument between a father and son both of whom belonged to a group that practiced cannibalism. MacEwan says: "The argument had arisen because the son did not approve of eating other people. I recall particularly his lines: 'Eating people is wrong!' and 'I won't let another man pass my lips!' The father, in exasperation, kept saying, 'But people have always eaten other people!'” (1999: 145). MacEwan says that the father could have asked the son to provide an alternative to cannibalism since one could not "carry out social justice campaigns on an empty stomach or on a protein-deficient diet" (1999: 145).

The context to both anecdotes is redistributive justice, which is about recognizing the individual dignity of the poor by prioritizing their needs and making them self-sufficient; this is apart from the fact that neo-liberal economic policies have in fact justified the father's realism that defended "cannibalism" in the face of the son's idealism that people should not prey on other people. Any notion of social and political justice is predicated on the availability of a decent meal on a regular basis to everyone who is a member of a social order. The idea that a pet can get a palatable meal that might be denied to a man, woman or child creates a serious ethical problem, because as a species it is imperative that I think first and foremost of a human person before I venture to feed an animal. Far from being a universal assumption, the impetus to foreground the human person is a perspective that highlights the necessity to include the vast numbers of people who are outsiders to the debate as to what constitutes the human or who should be given human rights in the first place. William Schanbacher says that, "To even begin to discuss what human rights require, we face the fact that tens of thousands of people perish every day due to poverty and hunger. This simple fact is often lost upon many who dispute whether people should have inviolable human rights" (Schanbacher 2019: 142). When an animal can get a decent meal that a human being cannot have, for that particular individual it becomes essential to declare his or her humanity in universal terms as a way of appealing to conscience in the face of power. The reality of the one, who is deprived of a decent meal, is about how things should be rather than an acceptance of how things are; it is the former that forms the basis of an alternative argument that privileges a response to human suffering, especially one that comes from hunger, before any other living creature. This in no way is to speak for an exclusionary

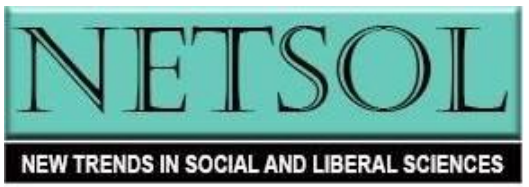


viewpoint that even vaguely might suggest that a person who is empathetic to animal pain is incapable of showing kindness to a human being. On the contrary, there is enough reason to believe and evidence to suggest that empathy is an intrinsic quality irrespective of towards whom it is manifested. The direction my paper takes is about human persons and the relevance of the food question in a human context. Therefore, I am inclined to believe that it should be the case that a man, woman or child who is hungry or not able to find enough to fill one's belly should deserve to be the focus of how we think about ourselves as a species.

The equally significant issue is if I have to "eat" another person to succeed in a bitterly competitive world: that creates a different set of ethical problems. Both the above perceptions are related to how we think about food; discussions related to ethics and politics are unthinkable where the bottom line is not food. Moral or political assumptions that do not touch on the question of survival which is fundamentally linked to obtaining a decent square meal without compromising on one's dignity operate under the view that the food question is not indispensable to human conduct. In his essay, "Global Hunger: Moral Dilemmas," Nigel Dower notes as the "precondition of human well-being-adequate food" (Dower 2002: 9). Adequate food underlies how we think in political and ethical terms; the first question that needs to be asked is whether an individual or a group has access to food. When we are not thinking about the hungry of the world or assuming that everyone has eaten, it is owing to the fact that we do not see ourselves as a "global community or society" where those who have are responsible for those who do not have and might be lacking in a "moral vision" that fails to recognize the need for such a responsibility (Dower 2002: 9). To every discipline in the humanities and social sciences we attach the word "food" from the politics and ethics of food to a philosophy and economics of food. A literature of food is about the artistic role that "food" as a word and concept plays in human languages; food as a metaphor of love is where hunger becomes synonymous with desire for the object of passion; alternatively, food is simply treated as matter to be consumed without a figurative dimension to it and not be reduced to feelings of love or any such noble sentiment; the assumption being that a person can think of something like love only after he or she has had a meal and not before that.

On a less analytical note, in one of the comic strip episodes from Calvin and Hobbes, Calvin tells Hobbes, "I don't understand this business about death. If we're just going to die, what's the point in living?" (Watterson 2016: 37). Hobbes is silent for a moment and then responds with a warm smile, "Well, there's seafood" (Watterson 2016: 37). Calvin is kind of disgusted by the banal response and grouchily replies, "I don't know why I even talk to you before dinner" (Watterson 2016: 37). From Hobbes's perspective, seafood is not a bad reason at all as an existential point to living. However, since it is a pre-dinner talk, Calvin expects a loftier goal to life rather than merely seafood. If seafood could resolve the mysteries of existence by forcing one to confront, what is of immediate importance, such as what we are going to eat for dinner, the question related to why we must continue living other than for the sake of eating is rendered meaningless at a more philosophical level. In other words, eating is the only reason why we need to live since there is no other basis for survival except through eating. Any debate on the goals of life must inevitably place food at the center of discourse. If we need to understand how eating ought to be connected to a discussion on life's meanings, rather than

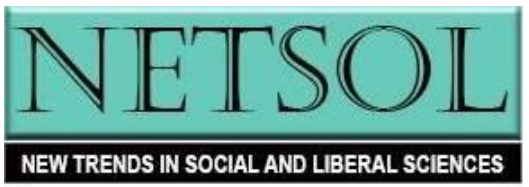


philosophy, it is in popular culture, especially films, that we observe the centrality of foodrelated matters. One of the important aspects of popular culture is that it operates at a level of comprehensibility that takes into account how a large segment of the population perceives itself on a surface plane without a complicated logic attached to the perception. Despite the fact that films by appealing largely to existing preconceptions, tend to homogenize social groups through speech, behavior or eating patterns, an insight is provided into a certain kind of articulation that portrays how individuals or groups expect to be seen by others. An understanding of those expectations gives an idea of how social reality is intertwined with basic human needs beginning with food.

While popular culture itself has been a fairly neglected area in more conventional disciplines, the centrality of food has often had to pave the way for problems related to the heart or the mind. A person's emotional and psychological life is prioritized as if it existed independent of his or her material existence; the argument that this paper makes is that the quality of one's personal life is manifested in the kind of food that he or she gets to eat rather than merely being satisfied at the level of feelings or in the mind with no reference to the stomach. Pablo Parasecoli observes, "Attention towards the body and the embodied self is growing not only among scholars and scientists but also in the media and popular culture" (2008: 86). Beneath the sentimentalism and tendency towards melodrama in mainstream films, what ought to be the case is a movement towards the recognition of the body as the source of art and philosophy. Parasecoli states, "We cannot underestimate the impact of communication on the ways we perceive, consume, and produce food" (2008: 147). The perception, consumption and production of food determine how people view themselves, how others look at them, their place in a social order and what goals they are able to set for themselves. Any insight into what constitutes a human being revolves around the basic right to food simply because "individuals who do not know when (or even if) their next meal is coming are, in that way, reduced to a subhuman existence. There simply is no human dignity in suffering from starvation or malnutrition" (Carey, Gibney and Poe, 2010: 91). The equation of bodily well-being, which comes with a proper meal, with human dignity forms the basis of how our communication is shaped by the perception, production and consumption of food. In fact, that is the essence of the language that we use; the metaphors we construct in the simple act of communicating with others; one perceives, one produces, and one consumes in order for one to be oneself. Having a proper meal is not just an analogy for the act of communication; it is communication in every sense of the term; the metaphors are built into how we use our body to make food in the same way that we make the language to not only talk about food but also our feelings.

The 1954 classic movie Salt of the Earth is about a strike by miners with the fictional plot surrounding the long strike of 1951 in New Mexico against the Empire Zinc Company for its discriminatory attitude towards the workers and for denying them basic amenities, such as hot water. The film's screenplay writer Michael Wilson, producer Paul Jarrico and director H. J. Biberman were blacklisted by the US House Committee on Un-American Activities for suspected communist affiliation. A significant part of the movie deals with the role working class women play in sustaining the strike by replacing the men on the picket line and how household issues become as important as the demand for equal treatment by the miners. The role of the

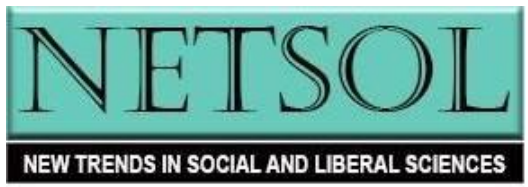


female protagonist Esperanza Quintero was performed by the Mexican actress Rosaura Revueltas, who was arrested, deported, and blacklisted for the character she played in the film. At the end of the film, when the slightly chauvinistic husband and father, Ramon Quintero, thanks the women and his wife in particular for her "dignity," Esperanza, who is also the narrator's voice, ends the movie with the powerful lines: "Then I knew that we had won something they could never take away. Something that I could leave to my children. And they, the salt of the earth would inherit it" (1954). One particularly telling instance in the movie is when the women are put in a prison cell and Esperanza is desperately in need of formula milk for the infant in her arms. The women collectively scream "Formula, Formula" exasperating the police (1954). The husband who happens to visit the prison to see his family takes the infant and his other children back home with him. By turning basic necessities as the goal of a strike and in empowering the "sisters" - the wives and mothers among the working classes, the movement for transformation (as I consider the strike), makes a larger point which is to make food and decent housing conditions central to how we struggle for material needs in the social world. More importantly, it raises issues related to personal commitment in the accommodation of others, as the men are forced to recognize that the women had more to endure because of the poor working conditions along with having to bear the burdens of life at home. The movie touches on larger issues of people having to come together cutting across gender and racial barriers with a commitment to sharing of resources as part of the transformation which has little to do with the strike itself.

Recounting an incident during the making of the film, Biberman in the book Salt of the Earth: The Story of a Film, writes about a dinner that was planned to honor the women who had made the Empire Zinc Strike a success.

At a meeting to organize the dinner the president of the union had said they would require many committees and first of all a food committee - and what lady would volunteer to head that committee? Mrs. Ramirez rose and, addressing the chair, asked if the celebration were to honor the women? Of course! Then she believed the chair should ask what brother would volunteer to head the food committee because, personally, she expected to sit all through the celebration and be honored! And she was. The evening of the dinner the men were at the tables serving the food and cutting the hams and sweeping the floors. And they did so because they wished to. They were honoring their women because when the chips were down these women had been saviors of the union and of its gains for their families. (2003: 71)

In honoring the women by serving them food and sweeping the floors, the men expressed their genuine, heartfelt thanks for the women who saved the day with their grit and determination to pursue the strike at personal costs without losing faith in themselves. The point made both in and outside the film is that we cannot conceive of gender and economic equality, without food as an important aspect of living conditions, occupying the center stage of the discussion. The fact that people must eat before they embark on any other activity and the other equally important aspect that individuals have the opportunity to enrich their personalities through the quality of the food they have on a daily basis is a significant step towards equality in the real sense of the term. While the search for equality both for women and the deprived sections of society includes

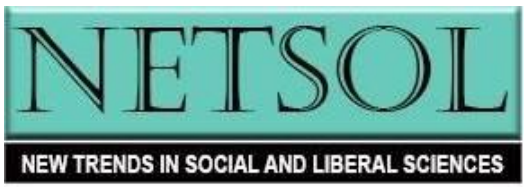


other things such as freedom from exploitation and the freedom for personal growth, it is impossible to imagine either of those freedoms unless they are reflected in the kind of food that one is able to have. By honoring the women for the success of the strike through the symbolic gesture of serving the food and cleaning the floors, the men acknowledge that eating matters are a priority and a way forward towards an egalitarian order of things.

The making of the film which dealt with the salt of the earth, a Biblical metaphor for the masses, literally dealt with salt-related matters, those concerning the daily business of living and how the men treated the women and the children etc. Part of the saltier side of the earth lay in recognizing the strength of the weak and in giving them a chance to run the show. James Lorence observes, "The Ladies Auxiliary assumed major responsibility for a variety of tasks essential to the project's completion, including not only child care and food management, but also publicity, communication, and transportation... Sonja Biberman helped the men to see their "responsibility to provide child care," which, in turn, was important in "making the film possible"" (1999: 74).

At the end of the day or the beginning for that matter, it is as much about food as it is about social relations formed through the attempts to find and make food that determine the meanings that people give to their lives. People are involved with one another in the process of satisfying material needs while at the same time looking for social acceptance and dignity. The importance of translating the feelings of injustice that inspired the strike to how people treated one another in day-to-day life while in the process of making the film itself cannot be overestimated. At some point in the film, conscientious behavior takes precedence over ideological commitment. The fact that emerges is that not all ideologically committed people are conscientious and not all conscientious people are inclined to look at the world through the prism of ideology. At the level of interpersonal relations, how the husband regards the wife, how the men view the women and how people in general treat one another - these things become a matter of empathy and conscience rather than formulaic statements. The success of the strike and the success in the making of the film are more so because both evoke the poetics of conscience rather than an imaginary ideological war between the haves and the have- nots with no reference to how power operates at the interpersonal level. What ought to be the focus is the binding, humane aspect of making and sharing food which adds to the strength of the interpersonal relationship, thereby in effect building stronger community bonds; such bonding also alleviates the bitterness and stereotyping that happens where people are distant from each other's needs. Representations of workers going on strikes for food or decent wages enabling them a life of "dignity" continued into the 60s, 70s, and 80s. In fact, more and more, a decent meal, hot water or enough sleep to allow the body to recuperate on a daily basis is equated with what the word "dignity" means in the sense with which Esperanza uses the word in Salt of the Earth. The 1963 Italian film The Organizer, with Marcello Mastroianni playing the main character of Professor Sinigaglia, is an example of a fictionalized strike in the industrial city of Turin at some point towards the end of the nineteenth century. The focus of the struggle is again for reducing a fourteen-hour long working day to thirteen hours in order to avoid accidents resulting from utter exhaustion. Strikes, usually for basic things, such as clean food, drinking water and reasonable working hours, most of which tend to be taken as human rights in a current scenario, were a frequent phenomena during the early half of the twentieth century especially during the war

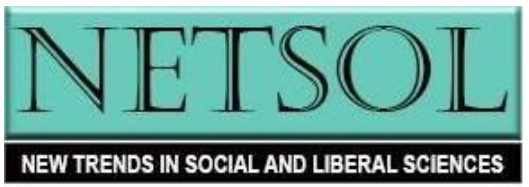


years and in between. In an article about Gramsci during the "Turin Years," Megan Trudell notes that,

Frequent demonstrations in the countryside against conscription, requisitioning and food shortages increasingly assumed a political dimension, often leading to violence against the police and wealthy citizens...In August 1917 a general strike began in Turin after police killed two people during a protest over bread shortages. It quickly became a powerful expression of a potentially revolutionary anti-war movement. (2007)

The masses in their opposition to fascism recognized that what brought them together was the consciousness of basic needs and the fact that this consciousness in itself could become the basis of a larger theoretical position in relation to the working class struggles as a whole. Gramsci writes about the Turin movement,

It gave the masses a "theoretical" consciousness of being creators of historical and institutional values, of being founders of a State. This unity between "spontaneity" and "conscious leadership" or "discipline" is precisely the real political action of the subaltern classes, in so far as this is mass politics and not merely an adventure by groups claiming to represent the masses. (1992: 198)

Most of the movements, far from being adventurist, culminated in the struggle for bread. Anti-fascism in one form or another also meant pro-bread struggles and Ignazio Silone's novel Bread and Wine generously makes the point. On the one hand, bread was the basis to the struggle. On the other hand, to be prepared for hunger is one of the ways in which a resistance could be prolonged. The need for bread and a theoretical consciousness with bread as the meaning of the struggle for the subaltern classes embarking on mass politics shaped the direction of social movements on the question of transformation. Bread consciousness is the awareness of bread in a broad sense to mean edible food, health, and a decent living as central to who we are as individuals and how we experience social life while a theory of bread is where bread is treated as an idea that could be examined for its practical implications in a real-life situation as if it were only an idea and nothing else. In other words, instead of a theory of bread what we need to have is the consciousness of bread without which no theory would be possible. Popular representations of struggles that equate bread consciousness with a quest for autonomy, selfreliance, and a voice for change are significant because they continue the argument made in Salt of the Earth. In a woman worker-centered movie Norma Rae from the late 70s, where the main character is played by Sally Field, we see a struggle that succeeds in the protest against poor working conditions because the workers could unionize themselves. The 1987 movie Matewan similarly dramatizes the struggles of miners to form a labor union with the management opposed to the idea thus resulting in a battle between the miners and the Baldwin-Felts Detective Agency.

The fight for dignity as manifested in the fight for bread, for salt, or for a piece of earth is significant, though another thing that needs to be borne in mind is that the poor are not caught in the consumerist trap in any of the situations portrayed through the movies. Being poor might in itself not necessarily entail a loss of self-respect. Ordinary men and women living a life of basic subsistence might take genuine pride in who they are as individuals without having to give up their dignity as human beings. The fight for bread is ultimately about having a sense of self

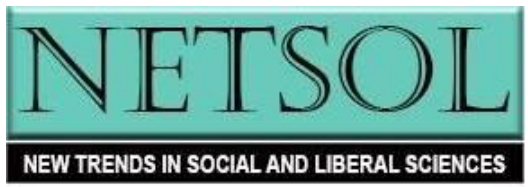


which does not have to submit to a loss of personal autonomy even where it has to endure economic deprivation. Eric Hobsbawm while making the following observation about Spain in the 1950 s notes that

it was the absence of that great corrupter of morals, the mass tourism of the rich in the territories of the poor, which allowed the Spaniards of the time to keep their traditional pride. Nothing struck me more in those days than the insistence of poor men and women on maintaining relations of reciprocity: not accepting a cigarette without offering one in return, or refusing a brandy from an evidently better-off Englishman, which was not compatible with equivalence, but accepting a coffee, which was. In my experience foreigners had not yet become essentially sources of income for poor natives, not even when - as in 1952 - they arrived in Seville, as I did with some student friends, in an evidently British yacht and moored in town, just opposite the as yet ungentrified bars of Triana. (2008: 344-45)

It is one thing that the poor that Hobsbawm speaks of were not corrupted by the mass tourism of the rich. It is another thing that they retained a sense of pride in who they were and insisted upon maintaining "relations of reciprocity." The association of struggles for bread with a struggle for dignity is a peculiarly late nineteenth and twentieth century phenomenon and Marxism, not to mention Marx himself, might have played no small role in the endeavor to bring bread as an expression of human dignity to the forefront of political discourse. Engels in the funeral speech at the Marx's grave notes that: "Marx discovered the law of development of human history: the simple fact, hitherto concealed by an overgrowth of ideology, that mankind must first of all eat, drink, have shelter and clothing, before it can pursue politics, science, art, religion, etc." (1993). By putting eating and drinking ahead of everything else, Marxism created the framework through which all future struggles will operate in addressing questions related to social justice. This might not have much to do with Marxist principles as much as with the fact that issues related to eating and drinking will have to be addressed in articulating the goals of a struggle. While socialists and reformers recognized the importance of food, it was seen as a means to survival thus occupying a secondary position in relation to ideas that fed the mind. In making "eating and drinking" the basis for politics, science, art and religion, Marxism radically alters the equation so much so that Bertolt Brecht contemptuously writes in one of his poems, "Amongst the highly placed / It is considered low to talk about food. / The fact is: they have Already eaten. / The lowly must leave this earth/ Without having tasted/ Any good meat." (1976: 286). In the same set of poems, Brecht says: "Those who take meat from the table/ Teach contentment... Those who eat their fill speak to the hungry/ Of wonderful times to come" (1976: 287). In mocking those who refuse to take "food" as an intellectual discourse that needs to be seriously debated, Brecht rightly observes that the ones "who eat their fill" can afford not to talk about it. This is not to forget that so much of the language of protest especially when it comes from the bottom is connected to food.

If, in Brecht's poem, those who have "already eaten" are not interested in talking about food, it is because they cannot bear to listen to the language that, by way of protest, reminds them of the fact that they have already eaten. The acute consciousness of being poor stripped of all ideological accoutrements is associated with food and sleep more than anything else.

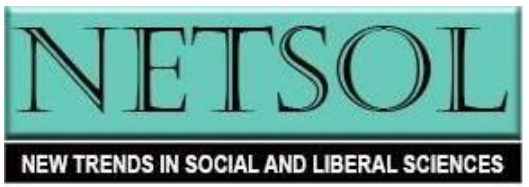


Historically, food shortages have been known to spur hungry masses into immediate action. Resistance politics surrounding food-related issues often takes violent forms.

Food riots had long been a common form of popular protest, but they reached new intensity worldwide in the eighteenth century, precisely when food supplies were becoming more dependable overall. In 1789, Parisian women marched on Versailles to drag "the Baker" - Louis XVI - back to the capital and thus guarantee access to bread. Muslim women had staged an equally symbolic protest four decades earlier by occupying the minaret of Aleppo's Great Mosque during prayer to hurl abuse at the Ottoman governor for negligence in times of famine. When the town council of Querétaro, Mexico, could not stem the high price of food in 1749, a mob rampaged through the streets and attacked the public granary. China maintained the most comprehensive granary system of the pre-modern world, but nevertheless, crowds of hungry people regularly looted storehouses and blocked shipments of rice. (Pilcher 2006: 42)

The right to food as a social right, which only means that by simply being born into a social order, one is entitled to a meal, might be as old as history itself. Food, as a human right, where, to have access to a decent meal is an assertion of my dignity as a person, is a much more recent phenomenon, and can be traced to the French revolution. Though there is an overlap in the definitions, a social right is what is made by a person as a member of a group, while a human right is exercised by individuals who may or may not subscribe to any particular group membership. A hungry and homeless person is still entitled to his or her humanity and by extension rights associated with the acknowledgement of one's humanity irrespective of the fact that they might not belong or be a part of any social or political space. Human rights make a claim to universality that social rights usually do not, simply because in the case of the latter, as a member of a larger group, such as a nation-state, the realization of my expectations are connected to those who have the power to make decisions that can alter my situation in this specific domain rather than across humankind. In recognizing the significance of the social right to food, religion played a part in instituting charity as a value with long-term spiritual benefits, thus ensuring that the poor were not completely neglected by the rich and powerful.

In medieval Europe, the Catholic Church demanded a "moral economy" and condemned merchants who overcharged consumers for basic foods. During normal times, the "just" price was simply the market price, but when famine struck, authorities were morally bound to intervene in the market and guarantee subsistence for the poor. Such paternalistic action was essential for ensuring stability in rigidly hierarchical societies, not only in Europe but around the world. Conquistadors carried the notion of a just price to the Americas, where reciprocity was already well established. Confucian teachings demanded a similar concern for the poor, as did Islamic requirements of charity. (Pilcher 2006: 42-43)

For any state and government, social stability is an issue and food or the lack of it could cause an immediate crisis which could jeopardize the order as a whole. Owing to the replacement of a paternalistic "moral economy" that gave the poor some kind of assurance in not being completely abandoned by the social order with the "capitalist logic of a new "political economy" (Pilcher 2006: 43), the notion of human rights connected to individual needs becomes

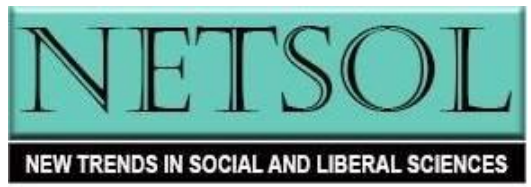


foregrounded. Irrespective of whether I belong to a group or not, and even if I am a prisoner, refugee, or a stateless person, I am entitled to make demands with regard to my well-being especially when it comes to satisfying hunger, primarily owing to characteristics I share with other human beings cutting across social and political differences. The question of social justice being connected to redistribution of resources creates the space for the human rights argument in relation to everyone being equally entitled to food simply because they happen to be people. If the poor continue to appeal to conscience or the guilt of the "haves", it is because they persist in effectively using a value from the moral economy in a political economy where charity towards one's neighbor is looked at with disdain if not complete indifference. In fact, the human rights argument, while acknowledging the presence of an autonomous subject, who can articulate his or her needs, does not completely reject the traditional "social" argument in favor of a conscientious response to issues, such as hunger and poverty. While I make assertions of the consideration I deserve as a human person, I could still appeal to someone's sense of justice or innate goodness and expect them to respond positively to my feelings of discrimination.

It is hard to deny that apart from the embourgeoisement of the working classes, we owe it to those who "have already eaten" for having successfully replaced bread politics with the politics of identity in the second half of the twentieth century. Wherever identity, which exists in the realm of the metaphorical, became central to a group, the question of acting with humanity towards people unlike oneself ended up occupying the secondary status of the literal. The figurative parameters associated with identity, which give an exaggerated sense of oneself, are denied to people who are not a part of one's group. There is a tendency to assume that since others do not share qualities that we possess by virtue of a certain identity, they could be rendered to the realm of the "literal" which means I do not have to be responsible to them in any way because they are not a part of what constitutes my imagined selfhood.

The pride, as in self-respect, which came with a decent square meal as the basis for some kind of autonomy, had the unfortunate consequence of encouraging the poor and the middle classes to believe that ownership of objects of consumption is more important than a fight for basic amenities including food itself. In separating food from the demand for self-respect thanks largely to identity politics, the result became political correctness in using language in public spaces and consumerism when it came to lifestyle. The appearance of seeming neutral became far more important than the ethical questions surrounding neutrality. This seemed the ideal way of dealing with resistance politics, which ignored ground-level realities and took the mediaconstructed version of what people wanted much more seriously than it deserved. Consumerism complemented political correctness in creating new identity-based lifestyles through objects, such as clothes and Che Guevara t-shirts on university campuses are the best example of how radicalism has been reduced to tokenism. The dignity that the Spanish poor displayed in not allowing rich tourists to patronize them with their spending power speaks volumes for the pride they took in themselves as they were and not as what others would want them to be. The accomplishment of a bread-based politics is that it gives the poor the kind of pride which does not lend itself to a schizophrenic situation where a feeling of social inferiority has to be compensated for with an arrogant and aggressive disposition that comes with an obsession with things. The loss of food-based self-respect in favor of ethnic and national identities that also gave

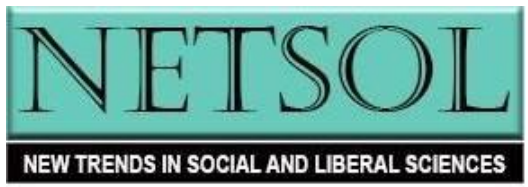


some kind of a conviction but at the expense of one's individuality is a crisis of untold proportions. It is through food that one acquires a sense of reality in relation to one's body. The loss of that sense of reality consequently meant turning people into ideas that could be toyed upon without conflicts of any kind.

To connect dignity with the well-being of the body is a familiar theme and the long journey of the Joad family from Oklahoma to California in John Steinbeck's 1939 novel The Grapes of Wrath forcefully evokes the landscape and the power of human endeavor to overcome human-made barriers that come in the way of self-assertion. Tom Joad apocalyptically speaks of his own self in universal terms towards the end of the novel:

I'll be all aroun' in the dark. I'll be ever'where- wherever you look. Wherever they's a fight so hungry people can eat, I'll be there. Wherever they's a cop beatin' up a guy, I'll be there...I'll be in the way guys yell when they're mad an'- I'll be in the way kids laugh when they're hungry an' they know supper's ready. An' when our folks eat the stuff they raise an' live in the houses they build- why, I'll be there. (2000: 287)

Tom realizes that in his fight for dignity he cannot be a small person any longer and that he must intervene and not merely empathize in the struggles of people everywhere - wherever hungry people are fighting for food or wherever kids laugh with joy knowing that supper is ready. The right of hungry people to be fed is viewed at a fundamental level which is emotional and spiritual as much as it is physical and political. For all his revolutionary talk, Tom is relying on common sense in placing food at the center of social and political change as he is only too aware that questions of identity are irrelevant to poor, landless peasants.

A revolutionary, Marxist poet like Nazim Hikmet uses bread, salt, and water to express his love. In one of the poems, he says, "I love you/ like dipping bread into salt and eating/ Like waking up at night with high fever/ and drinking water, with the tap in my mouth." If the taste of bread and water is connected to one's survival, the love one feels for another person can only be as great as one's need to survive. By relating eating and drinking to an abstract notion, such as love, Hikmet declares his oneness with the salt of the earth. The metaphors of bread, salt, and water cannot be other than the truth that we need all three of them to live even if paradoxically, such a truth could only be stated through the use of a figurative comparison. Although bread, salt, and water are metaphors of love, they cannot exist in the purely figurative condition if they did not in truth sustain the body. If there is indeed something called love that is meant to sustain the soul, it can only happen because the body that needs bread, salt, and water will serve as the basis for the loving. It is hard not to share MacEwan's indignation when a dog is fed better than a human being or the skepticism of the father about the son who, coming from a group of cannibals, wishes to heroically give up the barbaric practice of eating others. Both are instances of a life where people do not have be worse off than dogs or suffer being consumed by inhuman greed. I choose to stand up for myself and in the act of doing so enable others to do the same for themselves.

If political correctness acts as a moral policing of the language we use, it is consumerism that provides us with the choices given by a market that turns eating from a need to live with dignity to a way of experiencing life without a notion of tomorrow to it. Calling America "one

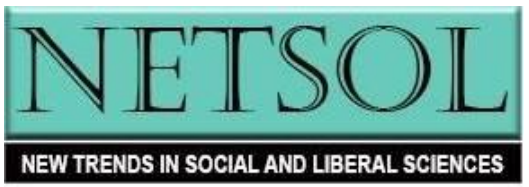


big transcontinental commercial cesspool" the stand-up comedian George Carlin bitterly protests against the culture of consumerism that has become a way of life with ordinary Americans.

Americans love the mall...That's where they get to satisfy their two most prominent addictions at the same time: shopping and eating. Millions of semi-conscious Americans day after day shuffling through the mall shopping and eating. Especially eating. Americans love to eat. They are fatally attracted to the slow death of fast food. These people are efficient, professional, compulsive consumers. It's their civic duty. Consumption. It's the new national pastime...The only true lasting American value that's left. Buying things. People spending money they don't have on things they don't need...And they didn't like it when they got it home anyway. (2007)

Carlin's biting critique of mall-style consumption patterns is the face of "global consumerism" and could be observed in people in the developing nations of the third world as well. Speaking at the "launch of a report on meeting millennium development goals, prepared by the UN Economic and Social Commission for Asia and the Pacific (ESCAP)," Jairam Ramesh, who then headed the Ministry for Rural Development with the Additional Charge of the Ministry of Drinking Water and Sanitation, noted that "Women make demands for mobile phones, not for toilets. That is the mindset we have" (2012). He further added: "India accounts for 60 per cent of open defecation in the world and this is a serious problem. Sixty per cent open defecation in a country that has 700 million mobiles!" (2012).

The distinction between the perception of what people believe that they do not have and therefore require as opposed to what they really need throws light on notions of what they view as a life of dignity. If eating as metaphor denotes a way establishing a relation with the world around one, even an act of fasting unto death is still about retaining that relation. While focusing "specifically on discourses and metaphors of food because they prove useful for unpacking the operations of ideology" (2013: xxx). Chad Lavin, in his book Eating Anxieties: The Perils of Food Politics notes that "eating constitutes such an intimate engagement with other beings and the material world, the discourse of eating consolidates and intensifies broader feelings about the relations between self and other, between public and private, and between human and nonhuman" (2013: xxx). If eating is about becoming oneself and not merely an act of survival, the moral dichotomy created through the proverb that one eats to live and not lives to eat, which implies that I must eat to live but I cannot make eating the goal of my life, is fraught with serious problems. To literally exist for eating or by way of metaphor to have goals for one's existence which are not about eating - the real as opposed to the ideal, where eating can be the basis for idealizing but cannot be the ideal itself, this kind of a distinction indirectly feeds into the logic of consumption. At the level of ingesting an idea one must always avoid talking about food; but, one can always indulge oneself in ideas about food through virtual reality in the same way that pornography plays a role in celebrating an idealized sexuality for the benefit of the consumer.

Both consumerism and political correctness operate within the domain of the ideal because they are not meant to serve any real purpose. As long as one is in control of one's language and restricts it to some kind of objectivity, which has no immediate reference to "objects" one could comfortably be a racist, classist, misogynist, and casteist. Likewise, one could consume to the point of distraction, but one need not be thinking about eating at all.

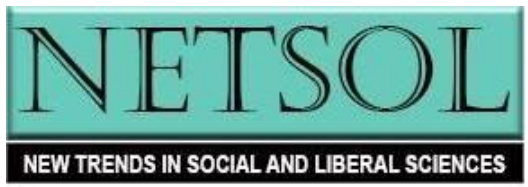


Alcoholics and drug addicts are ideal consumers because they transcend the need for pleasure and enter the domain of habit. Shopaholics, not very differently, indulge in the same fantasyfeeding mechanism that is supposed to act as guarantee for some kind of happiness. How do we digest the truth that pleasure is literal and not a metaphor! Consumerism and political correctness parasitically thrive on metaphor for sustenance because they are alienated from the literal. They want the hierarchy to be maintained wherein those who have "already eaten" can indulge in words without having to worry about the literal, which is food itself. Once the distinction between the metaphorical and the literal is rejected, and instead the context of the usage of a term is taken into account, then it is possible to talk of food and eating in a way that would literalize the metaphorical and metaphorize the literal.

While defining metaphor "as understanding one conceptual domain in terms of another conceptual domain" (2002: 4), Zoltán Kövecses further defines a conceptual domain as "any coherent organization of experience" (2002: 4). For instance, to say that a friend is a rose is to selectively dwell on qualities related to appearance. It is understood that a friend produces feelings of beauty just as a rose would do upon sight. Thus, to understand has a specific meaning as "a set of systematic correspondences between the source and the target" (2002: 6). When attempting to understand metaphors related to eating in connection with other conceptual domains, such as love, one needs to examine the "correspondences" between eating and love. A statement such as, "I could eat you just now" could mean someone is gorgeous enough to be "eaten". It could also mean, I am so mad with you that I could eat you. Kövecses observes that in the use of a metaphor some of meanings are usually highlighted while the others remain hidden (2002: 80). According to Kövecses, in a metaphor such as "Love is a nutrient," what happens is that

many things in connection with nutrients are left out of this picture. For example, no reference is conventionally made to the idea that nutrients come into the body from outside; that we digest nutrients in order to process them; that eventually some of the nutrient goes out of the body; that we may have to go out and buy nutrients; that we store them in the refrigerator or the pantry; that nutrients may go bad and can make us sick; and many more. (2002: 82)

It is inevitable that in a metaphor some meanings only can be considered and others less focused upon. What usually happens though is that the more mundane, literal aspects end up being relegated to the status of a second-class citizen. The simple fact is that depending on the context and how a word or sentence is used, the literal becomes the metaphorical and the metaphorical the literal. Josef Stern drives home the point in his book Metaphor in Context:

The distinction between the metaphorical and the literal, on the other hand, is a distinction between two kinds of interpretations or uses of language, not between kinds of truth, or between the circumstances in which what is said is true or false. Metaphors no less than literal utterances of sentences can therefore be actually true-just in case their interpretation, or what they are used to say, is true in the circumstances in which they are uttered. (2000: 304)

Distinctions are made for the purposes of categorization. In the politically correct version of things, the categories become ends in themselves. The consumerist depends on the metaphor

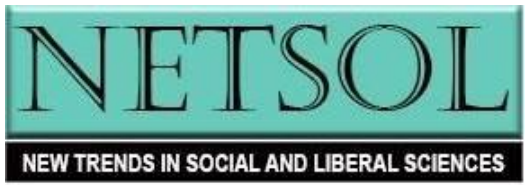


for his or her existence, but in this case the metaphor is taken literally. The truth needs the literal such as a dog is a dog but hotdogs are not dogs. If the literal is taken as another version of the metaphorical, then, an interpretation of what is out there is derived not from the outside but from within words themselves. To treat what is out there as truth, independent of the language used to talk about, is as problematic as entertaining the view that language has a determining role to play over that slippery terrain called reality. In acknowledging that there is something true of the world other than what is in one's own mind and that language in a sense describes it we are in the domain of interpretations, but only with respect to what can as faithfully as possible be said about a given situation. The consumerist, like the politically correct man or woman, looks at the world as a mental construct and therefore to be resolved mentally. The opposition between the literal and the metaphorical are kept alive for the purposes of retaining the distinctions that power makes with reference to reality. The literal is the "raw" enabling the metaphor, that is, the "cooked" to borrow a phrase from Claude Levi-Strauss. The truth as a description of an interpretation fills the space between the metaphor and the literal; a hotdog is anything but a dog, but you can have a dog named hotdog. Stern notes,

A literal (or one notion of a literal) interpretation is an interpretation...that can be assigned to a word relatively independently of its context and, in particular, independently of networks to which the word belongs. When a metaphorical interpretation of an expression becomes a literal meaning of the word, it becomes the meaning of the word - that is, an interpretation that can be assigned to the word independently of its contextually presupposed networks. Its content becomes a feature ofpossessed by-the word (type) -regardless of its containing schemas. This is the sense in which that content is literal-of the letter: of the word in isolation from its containing schema or context. Literal meaning is atomistic, unlike metaphorical interpretation, which, if not holistic, always depends on its containing context. (2000: 317)

The distinction that Stern makes is for the purposes of distinguishing, for instance, Charminar, the monument, from a particular area in the Old City of Hyderabad also known as Charminar where the former is located. The monument is presumed to have been built to symbolize victory over a cholera epidemic that struck the city. The context of victory over a dreaded disease is a part of the popular narrative mingled with other historical aspects. A monument can never literally be a structure with elements placed in a coordinated manner simply because a perceiver will attribute certain, specific qualities to it that are more than what is obvious while relegating the concrete, structural elements to the backseat. Since monuments occupy the space of memory, they also exist in a metaphorical space. Literally speaking, Charminar is a popular destination for tourists and locals, who wish to do shopping in bangles and other decorative stuff. But, to know Charminar is to experience it outside the domain of the literal. There is a meaning standing outside the context as in how one emotionally relates to an object, which has to do with the experience of the viewer, a rebel without a cause, in an oedipal conflict with the context, but, one that sooner or later must reconcile with or recreate the context in order to enable the flourishing of interpretations. While one may freely associate meanings with what one sees, somewhere the monument has to make its appearance in and through the multiple perspectives that a viewer brings to the context.

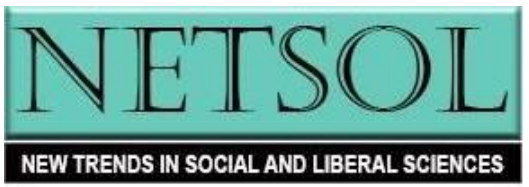


If the process of "dignifying" the poor, the old, and the wretched is only by means of language with an overemphasis on the autonomy of the linguistically correct political subject, who is expected to "believe" in his or her feelings, it becomes a way of alienating victims of inequality into accepting the argument that they are somehow responsible for their own fate. A politically correct understanding of victims makes it impossible for those in positions of power to take moral responsibility in how they deal with the poor. Where each one is supposed to be responsible for his or her situation the larger role of a political economy that perpetuates inequality is quietly washed away. Individual guilt for the plight of the many is not an issue in such an economy and the language is left to care of the reality. Now that the old are referred to "respectfully" as "senior citizens" one does not have to take the time to look after them or view them as dependents apart from the provision of institutional care wherever people could afford such care. The problem with respectful terminology is that more often than not it becomes an end in itself and nobody feels particularly responsible for the persons that need to be cared for; old age is human condition independent of the fact of whether we call the old as senior citizens or not. The reality of caring has to precede whatever changes that are expected to be made in the terminology.

If political correctness is not the response to the hungry of the world, it is because we are hiding behind words and allowing the latter to do the job that one ought to be doing which is to confront the truth as directly as possible. While "free speech" could be a blatant declaration of one's private feelings, which might simply be prejudices put together, the alternative, which is a more honest use of language where people are not constrained to express in a certain way merely because they wish to seem correct before an audience, could be equally troublesome if not outright insensitive. More importantly, the idea behind being allowed to speak freely even in democratic societies, often goes by the false assumption that everyone who speaks is heard equally - the CEO of a company and the janitor of the same company. What could be as problematic is when defenders of a particular cause - whether from the right or the left - take it upon themselves to invoke popular support to their demands. The real danger is in the infringement upon personal space or on one's right to hold an unacceptable political position while being part of a dialogue that is gravely threatened. Alan Wolfe rightly points out that

even though populism shares something substantive with liberalism, it is deeply illiberal temperamentally. Populism attempts to rouse people out of fear rather than to appeal to them through hope. It is strongly tempted to divide the world into friends and enemies. It has never been sympathetic toward those who live outside its rather restricted moral universe. It looks back with nostalgia toward a simpler past rather than anticipating a more complex future. (2009: 260)

A world that is divided between "friends" and "enemies" is built around the separation of the literal from the metaphorical. Everything by way of the literal gets attributed to the enemies who are presumed to be incapable of sophisticated explanations while the other things whose meanings are supposed to be deeper than what they purport to express are given to friends by way of the metaphorical. Temperamental illiberalism can threaten the foundations of an essentially democratic way of dealing with serious issues that matter across the board such as redistributive justice whose essence is that people have access to healthy food and healthcare by

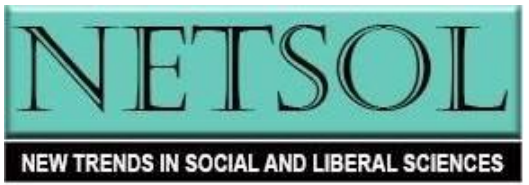


extension. Populist solutions are attractive because they are immediate and more often than not the very basis of electoral politics. The argument proposed in this paper is more interested in a non-populist way of looking at the truth, without having to descend into euphemisms that enable you to stay on the right side of the law, and without having to compromise on the idea of a truth that is one step ahead of the language invented to talk about it.

The symbiotic relationship that the truth has with metaphor cannot be replicated where an idea enjoys the privilege of not having to examine the truth. An idea cannot be privileged as an agent that has nothing to do with the truth. The ethics of eating demands that we cannot have a customized language through a special set of words without looking at the needs of the persons in questions. We cannot not talk about food for one good reason: that there are people who have gone to sleep on empty stomachs. Once we agree that we need to talk about food and give it a context one way or the other, it becomes important to ethically engage with questions, such as whether a pet dog should be eating more than a human being or if it is right to consume resources where there are people who are affected by such consumption. Christian Coff observes:

To be answerable for our consumption demands not only that we say: "It's me who has consumed it". We must also be answerable for the effects of that consumption - and it requires resolution to act on one's vision of the good life. The effects of consumption must not only be sought in the present but, as we have seen, in the past and the future also. The consumers' moral integrity therefore requires a will to know about the production history and to act (also commercially) in accordance with their ethical convictions. The production history of the food is important in many ways, not least because giving something a history is tantamount to ascribing a meaning to it. (2006: 165)

To be able to know what we need and whether we are able to have it and the nature of the consequences that our having it could have on others shapes our ethical understanding of the world around us. As important as the association of history to fact is the relation between a study of the past and what kind of meaning we are able to give events in the light of the present. We cannot have a history of food without at the same time defining in important ways our relations with people around us. We are historicized in the process of how we talk and think about food. The conventional opposition that prioritizes eating to live rather than living to eat can be an ahistorical statement; in the end we need to go by the logical assumption that the one who lives to eat is also able to think about issues surrounding living which might not necessarily include eating. I cannot say that I eat to live and stop with that; once the eating has assured me of life I can afford not to think about food except in figurative terms. Once we are able to reconcile the two different aspects, that language could be used creatively as metaphors and truthfully as facts, we accept that unless we view food as the goal of our existence we cannot arrive at existential goals that transcend a historical framework. Food is not a substitute for history or ethics; but questions about food test our moral integrity in our willingness to learn and share natural and human resources without which we cannot exist as a species.

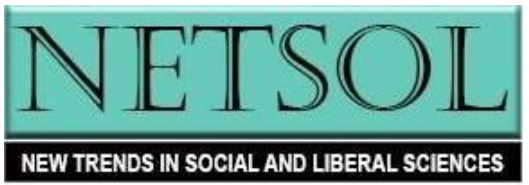




\section{References}

Biberman, Herbert. 1954. Salt of the Earth. Film. United States: Independent Production Corp.

- 2003. Salt of the Earth: The Story of a Film. Fiftieth Anniversary Edition. NY: Harbor Electronic Publishing.

Brecht, Bertolt. 1976. Poems: 1913-1956. Edited by John Willett and Ralph Manheim. London: Eyre Methuen.

Carine, Sabine C., Mark Gibney and Steven C. Poe. 2010. The Politics of Human Rights: The Quest for Dignity. Cambridge: CUP.

Carlin, George. 2007. Life is Worth Losing. DVD. United States.

Coff, Christian. 2006. The Taste for Ethics: An Ethic of Food Consumption. Trans. Edward Broadbridge. Dordrecht, The Netherlands: Springer.

Dower, Nigel. 2002. "Global Hunger: Moral Dilemmas," Food Ethics. Ed. Ben Mepham. London and New York: Routledge.

Engels, Frederick 1993. "Frederick Engel's Speech at the Grave of Karl Marx." Transcribed by Mike Lepore. https://www.marxists.org/archive/marx/works/1883/death/burial.htm. Accessed on November 10, 2019.

Gramsci, Antonio. 1992. Selections from the Prison Notebooks of Antonio Gramsci. Translated by Quintin Hoare and Geoffrey Nowell Smith. NY: International Publishers.

Hikmet, Nazim. 2018. "I love you." Poem. https://www.poemhunter.com/poem/i-love-you-632/ Accessed on November 10, 2019.

Hobsbawm, Eric. 2008. Interesting Times: A Twentieth-Century Life. London: Abacus.

Kövecses, Zoltán. 2002. Metaphor: A Practical Introduction. Oxford: OUP.

Lavin, Chad. 2013. Eating Anxiety: The Perils of Food Politics. Minneapolis: UMP.

Lorence, James J. 1999. The Suppression of Salt of the Earth: How Hollywood, Big Labor, and Politicians Blacklisted a Movie in Cold War America. Albuquerque: The University of New Mexico.

MacEwan, Arthur. 1999. Neo-liberalism or Democracy? Economic Strategy, Markets and Alternatives for the 21st Century. London: Zed Books.

Monicelli, Mario. 1963. The Organizer. Film. Italy.

Parasecoli, Pablo. 2008. Bite me: Food in Popular Culture. NY: Berg.

Pilcher, Jeffrey M. 2006. Food in World History. NY: Routledge.

Ritt, Martin. 1979. Norma Rae. Film. United States: 20th Century Fox.

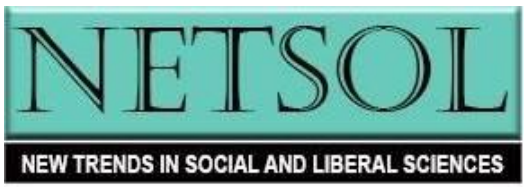


Sayles, John. 1987. Matewan. Film. United States: Cinecom pictures.

Schanbacher, William D. 2019. Food as a Human Right: Combating Global Hunger and Forging a Path to Food Sovereignty. Santa Barbara: Praeger.

Silone, Ignazio. 2005. Bread and Wine. Translated by Eric Mosbacher. NY: Signet.

Steinbeck, John. 2000. The Grapes of Wrath. Intro. Robert DeMott. London: Penguin Books.

Stern, Josef. 2000. Metaphor in Context. Cambridge: MIT Press.

Trudell, Megan. 2007. "Gramsci: The Turin Years." International Socialism: A Quarterly Review of Socialist Theory 114. http://isj.org.uk/gramsci-the-turin-years/. Accessed on November 10, 2019.

Watterson, Bill. 2016. "Calvin and Hobbes.” Deccan Chronicle. October 13, 2016.

"Women demand mobiles not toilets: Jairam Ramesh." 2012. India Today, February 18. https://www.indiatoday.in/india/north/story/jairam-ramesh-women-demand-mobiles-nottoilets-93418-2012-02-18. Accessed on November 10, 2019.

Wolfe, Alan. 2009. The Future of Liberalism. NY: Alfred A. Knopf.

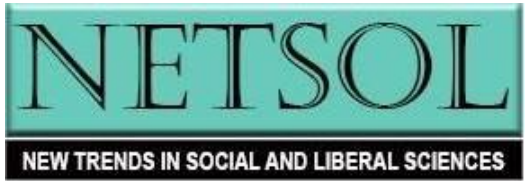

